\title{
MODELING THE DEEP DRAWING OF AN AISI 304 STAINLESS-STEEL RECTANGULAR CUP USING THE FINITE-ELEMENT METHOD AND AN EXPERIMENTAL VALIDATION
}

\author{
MODELIRANJE GLOBOKEGA VLEKA PRAVOKOTNE ČAŠE IZ \\ AISI 304 NERJAVNEGA JEKLA Z METODO KONČNIH \\ ELEMENTOV IN Z EKSPERIMENTALNIM PREVERJANJEM
}

\author{
Bora Sener ${ }^{1}$, Hasan Kurtaran ${ }^{2}$ \\ ${ }^{1}$ Yildiz Technical University, Department of Mechanical Engineering, Istanbul, Turkey \\ ${ }^{2}$ Gebze Technical University, Department of Mechanical Engineering, Kocaeli, Turkey \\ borasener84@gmail.com, borasen@yildiz.edu.tr \\ Prejem rokopisa - received: 2015-09-06; sprejem za objavo - accepted for publication: 2015-11-16
}

doi:10.17222/mit.2015.278

\begin{abstract}
In this paper the deep drawing of a rectangular cup from AISI 304 stainless steel sheet was investigated numerically and experimentally. The finite-element method was used for computer modeling of the deep-drawing process. The thickness distribution predicted from the finite-element analysis was compared with experimental measurements. It was observed that the numerical results agree well with the experimental values. The minimum thickness was observed at the punch radius in both the simulation and experiment.

Keywords: deep drawing, rectangular cup, finite element, stainless steel

$\mathrm{V}$ članku je bil numerično in eksperimentalno preiskovan globoki vlek pravokotne čaše iz pločevine iz nerjavnega jekla AISI 304. Za računalniško modeliranje procesa globokega vleka je bila uporabljena metoda končnih elementov. Iz analize končnih elementov napovedana razporeditev debeline je bila primerjana $\mathrm{z}$ eksperimentalnimi meritvami. Preiskava je pokazala, da se numerični rezultati dobro ujemajo z eksperimentalnimi vrednostmi. Najmanjša debelina je bila opažena na radiusu pestiča, tako pri simulaciji kot tudi pri eksperimentu.

Ključne besede: globoki vlek, pravokotna čaša, končni element, nerjavno jeklo
\end{abstract}

\section{INTRODUCTION}

The rectangular/square-cup deep-drawing process has specific forming characteristic. Non-uniform material flow and quite complicated deformation mechanism are seen in this process. Therefore, the deep drawing of square and rectangular cups is more difficult than that of some other shapes, such as circular cups. Many researchers investigated the rectangular/square-cup deep-drawing process experimentally and numerically. A. G. Mamalis et al. ${ }^{1}$ investigated the effect of material and forming characteristics on the simulation of the deep drawing of square cups by using the explicit non-linear finite-element code DYNA-3D. They considered the effect of material density, punch velocity and friction coefficient. L. F. Menezes and C. Teodosiu ${ }^{2}$ studied the square-cup deep-drawing process numerically and experimentally. They modeled the process by using solid elements and compared the numerical results with the experiment. E. Bayraktar and S. Altintas ${ }^{3}$ investigated the square-cup deep-drawing process and 2D-draw bending process of Hadfield steel experimentally. They evaluated the draw-in values of the flange, the principal strains in the square-cup deep drawing and compared the experimental results with that those of mild steel. Y. Ma- rumo and $\mathrm{H}$. Saiki ${ }^{4}$ studied differential lubrication methods in the square-cup deep-drawing process in order to prevent any deformation concentration on the corners. Y. Harada and M. Ueyama ${ }^{5}$ investigated the drawability of pure titanium sheets in the square-cup deep-drawing process. Titanium sheets were coated by heat oxide and formed into a square with a punch. L. M. A. Hezam et al. ${ }^{6}$ developed a new technique for the deep drawing of square cups made from brass and pure aluminum. They improved the material flow by using a conical die with a square aperture at its end without a blank holder. M. Gavas and M. Izciler ${ }^{7}$ designed a blank holder with a spiral spring to reduce the friction area between the blank and the blank holder during the deep drawing of square cups. A higher drawing height, a homogenous thickness distribution and minimum earing cups were obtained in their study. M. A. Hassan et al. ${ }^{8}$ have developed a new divided blank holder with a tapered base and eight tapered segments to increase the deep drawability of the square cups. They improved the drawability of thin sheets and foils and increased the limiting drawing ratio with this technique over the conventional techniques. L. P. Lei et al. ${ }^{9}$ studied the square-cup deep-drawing process for 304 stainless-steel sheet numerically and experimentally. They evaluated the effect of the blank 
shape on the material flow. J. H. Lee and B. S. Chun ${ }^{10}$ investigated the effect of temperature, blank shape and holding pressure on the deep drawability of a square cup from 304 stainless-steel sheet experimentally and numerically. F. K. Chen and S. Y. Lin ${ }^{11}$ examined the effects of process parameters such as punch radius, die radius, die corner radius, die gap and the length-to-width ratio by both the finite-element method and the experimental approach. The authors formulated a formability index that serves as a design rule for the rectangular cup drawing from 304 stainless-steel sheet. Although many significant studies are carried out about the rectangular/ square-cup deep-drawing process, they are generally limited to the forming of $\mathrm{Al}$ and $\mathrm{Al}$ alloys. Very little of the literature is devoted to the rectangular-cup deep drawing of 304 stainless-steel sheets. The available literature on the rectangular-cup deep drawing of 304 stainless steel sheets is limited to warm forming. Therefore, the cold forming of a rectangular cup from 304 stainless steel sheet is investigated numerically and experimentally in this study.

\section{EXPERIMENTAL PROCEDURE}

A die with a rectangular aperture, a conical punch that has flat surface with a rectangular shape and a circular blank holder that has a rectangular cavity are used in this study. The dimensions of the rectangular-cup tooling are given in Table 1. Deep-drawing experiments were carried out on a 160-ton-capacity double-action

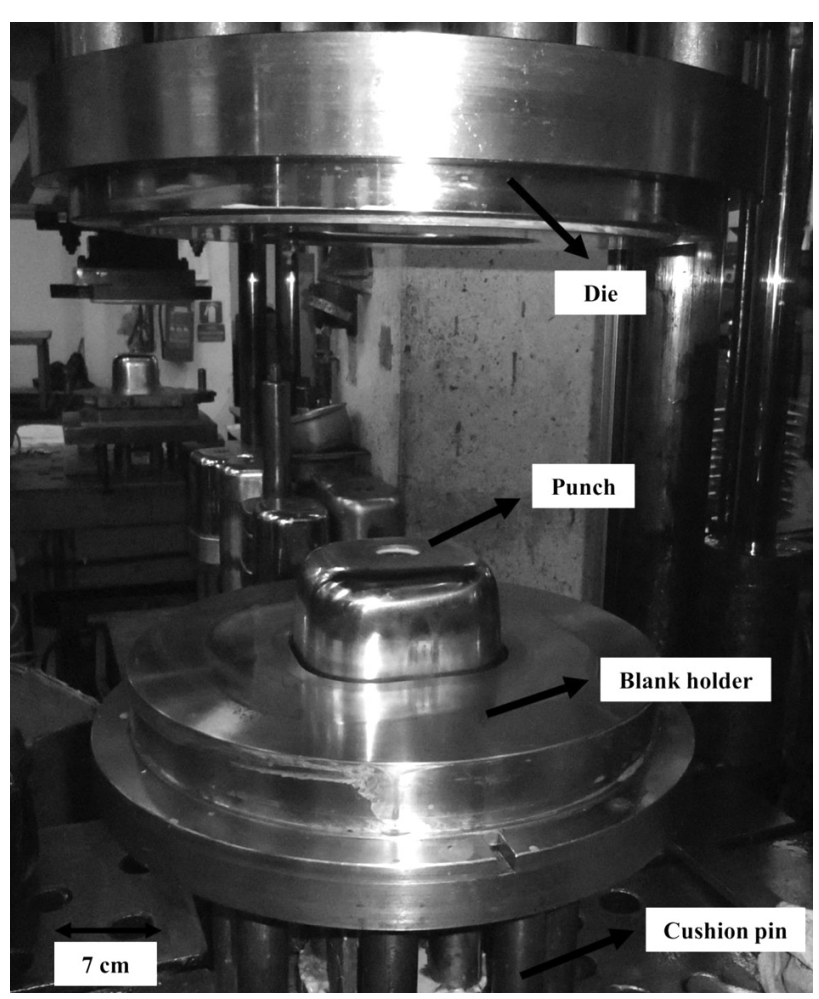

Figure 1: Experimental set-up

Slika 1: Eksperimentalni sestav hydraulic press. The punch is mounted to the lower shoe. The blank holder slides around the punch in the lower shoe. The upper shoe consists of the die. In the press, the lower shoe is mounted on the press bed and the upper shoe is attached to the press ram. The blank holder is supported by the cushion pins that apply the blank holding force to the blank holder during the forming process. During the deep-drawing process, the blank holder is raised to the top-most level. The blank is positioned on the blank holder. The clamped blank with the die and blank holder moves further down and forms the blank against the stationary punch under the action of the blank holder force through the cushion pins. The experimental set-up is shown in Figure 1.

Table 1: Tool dimensions

Tabela 1: Dimenzije orodja

\begin{tabular}{|c|lr|}
\hline \multirow{5}{*}{ Die } & Radius, mm & 35 \\
& Edge length of rectangular cavity, mm & $129 \times 143$ \\
& Corner radius of the rectangular cavity, mm & 47 \\
& Depth of the rectangular portion, mm & 27 \\
\hline \multirow{3}{*}{ Punch } & Radius, mm & 20 \\
& Rectangular side length, mm & $120 \times 134$ \\
& Cone angle, deg & 2 \\
\hline \multirow{2}{*}{ Blank } & Diameter, mm & 351 \\
holder & Edge length of rectangular cavity, mm $\quad 127.5 \times 142$ \\
& Corner radius of the rectangular cavity, mm & 45.5 \\
\hline
\end{tabular}

An austenitic grade AISI 304 stainless steel was used in this study. The thickness of the material was $0.8 \mathrm{~mm}$. The mechanical properties of the material are explained in Section 3. The initial blank of diameter $335 \mathrm{~mm}$ was drawn to a rectangular cup of height $80 \mathrm{~mm}$. A 340-kN blank holder force was applied in the experiments. The operating speed was $20 \mathrm{~mm} / \mathrm{s}$. A rectangular cup from 304 stainless-steel sheet was successfully drawn using the this blank holder force as shown in Figure 2.

\section{FINITE ELEMENT MODEL}

In the present work, the explicit non-linear finite-element (FE) code DYNAFORM 5.9.2 software is used for

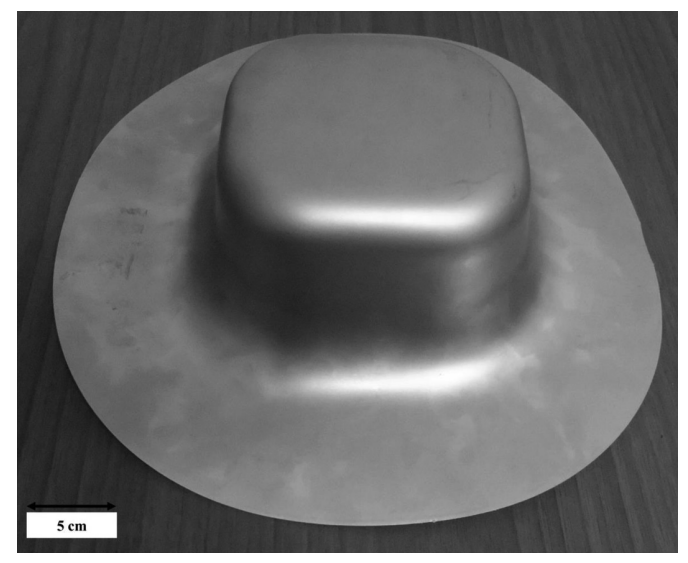

Figure 2: Rectangular cup

Slika 2: Pravokotna čaša 


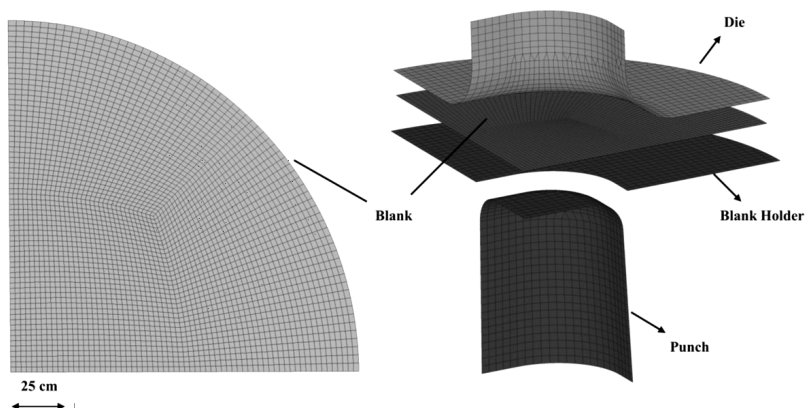

Figure 3: Finite-element model

Slika 3: Model končnega elementa

simulating the rectangular-cup deep-drawing process. The blank is meshed with 3333 quadrilateral elements and 3434 nodes. A Belytschko-Tsay shell element with five integration points across the thickness is used for the shell mesh of the blank. Because of the symmetry, only a quarter model is employed in the numerical simulation, as shown in Figure 3. The punch, die and the blank holder were modeled as rigid objects because of their high stiffness, while the blank was modeled as a deformable body. A forming-one-way-surface-to-surface contact algorithm is used in the analysis. The friction coefficients are assumed to be 0.11 for the contact between the tools (die, punch and blank holder) and the blank. This value was recommended by a previous investigation. ${ }^{12}$ The die speed employed is $1000 \mathrm{~mm} / \mathrm{s}$, which is extremely slow compared to the typical wave speeds in the materials to be formed (the wave speed in steel is approximately $5000 \mathrm{~m} / \mathrm{s}$ ). In general, inertia forces will not play a dominant role for forming rates that are considerably higher than the nominal $1000 \mathrm{~mm} / \mathrm{s}$ rates in the physical problem. ${ }^{13}$ The displacement of the die was taken as $80 \mathrm{~mm}$, which is decided by the height of the cup. A $85-\mathrm{kN}$ constant blank holder force is applied in the model (quarter of the experimental value). AISI 304 stainless-steel sheet is used in the simulation work. It is assumed that the material is isotropic and homogeneous. The strain-hardening model used is isotropic hardening. The mechanical properties of the material were determined by tensile testing. Different constitutive

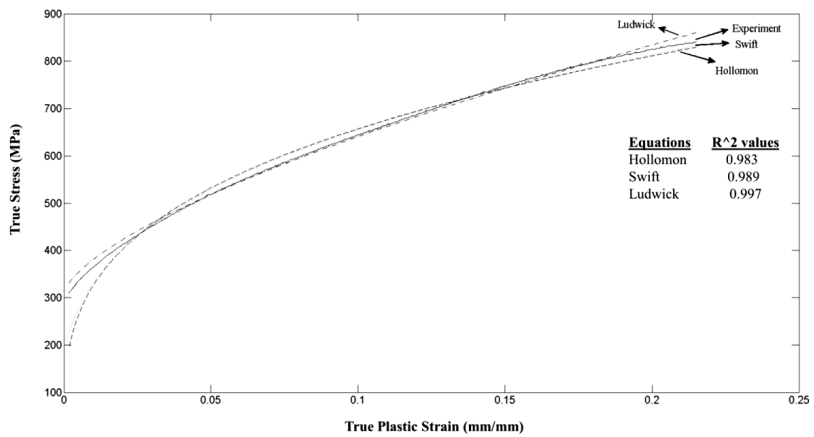

Figure 4: Comparison of the hardening models with experimental data

Slika 4: Primerjava modelov utrjevanja z eksperimentalnimi podatki equations, such as Holloman, Swift, and Ludwick, were evaluated in order to represent the plastic behavior of the AISI 304 stainless steel. The nonlinear least-squares method and a trust-region algorithm were used in determining the material parameters. It was found that the Ludwick equation was the best fit to the experimental data for the AISI 304 stainless steel. This result agrees with the literature ${ }^{14}$. The flow curve was extrapolated to higher strains using this equation and was used in the simulation. A comparison of these different hardening models with experimental data is shown in Figure 4.

The mechanical properties of the materials are reported in Table 2.

Table 2: Mechanical properties of the material

Tabela 2: Mehanske lastnosti materiala

\begin{tabular}{|l|c|c|}
\hline \multicolumn{1}{|c|}{ Parameters } & Units & Value \\
\hline Young's modulus $(E)$ & $\mathrm{GPa}$ & 256.86 \\
\hline Poisson's ratio $(v)$ & & 0.28 \\
\hline Yield strength $\left(\sigma_{\mathrm{y}}\right)$ & $\mathrm{MPa}$ & 308.94 \\
\hline Strain hardening $(n)$ & & 0.3 \\
\hline Coefficient of strength $(K)$ & & 1528 \\
\hline
\end{tabular}

\section{RESULTS AND DISCUSSION}

The thickness distribution is one of the major quality characteristics in the sheet-metal formed part. Therefore, the thickness distribution of the AISI 304 stainless-steel sheet in the deep-drawing process was investigated theoretically and experimentally. The drawn component was cut along the diagonal direction and the thickness of the part along this direction was measured using a micrometer, as shown in Figure 5.

For the verification of the FEM results, the thickness variations predicted by the numerical simulation were compared with the experimental results. Figure 6 shows the comparison of the FE predictions with the experiment for the formed part along section YO (diagonal). It could be observed from Figure 6 that the thickness

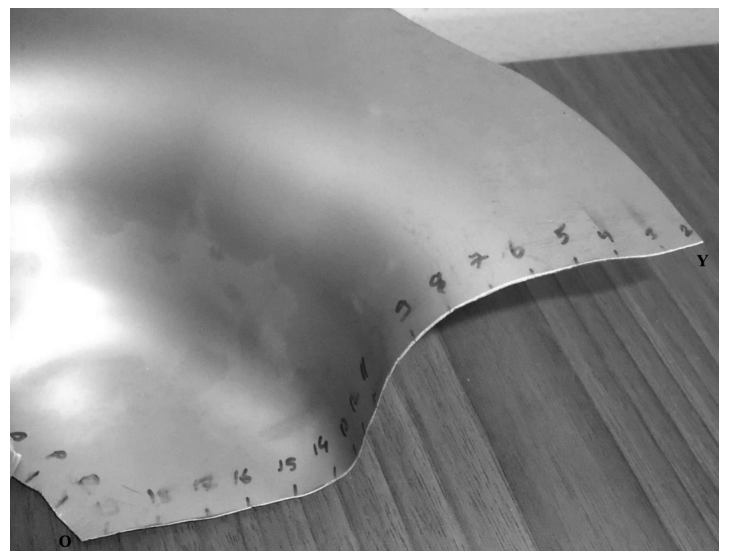

Figure 5: Location of the diagonal section in the formed part for evaluation of the thickness distribution

Slika 5: Prikaz diagonalnega preseka preoblikovanega dela za oceno razporeditve debeline 


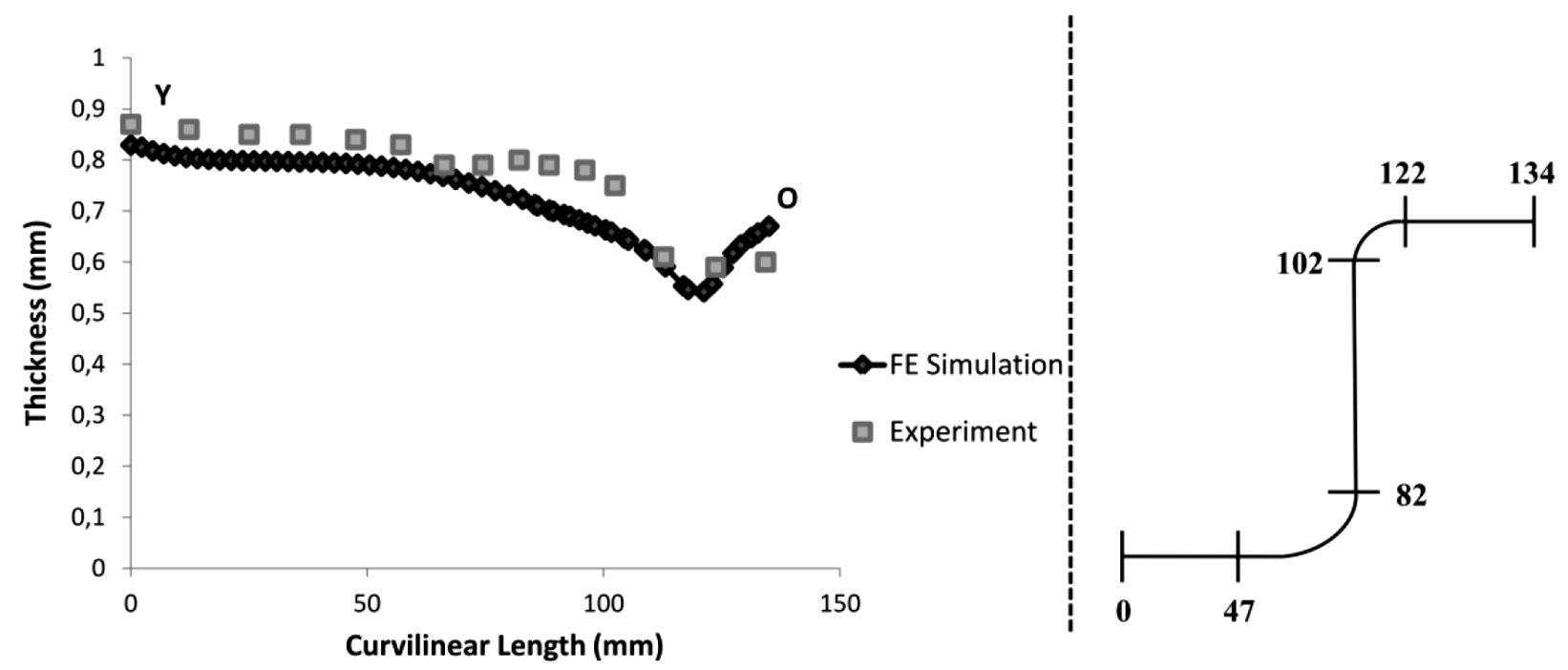

Figure 6: Comparison of the thickness distribution along section YO (diagonal) from FE simulation with experiments Slika 6: Primerjava razporeditve debeline vzdolž preseka YO (diagonalno) iz FE simulacije z eksperimentalnimi podatki

distribution predicted by the FE simulation along section YO agrees with the experiment.

A minimum thickness was observed at the punch radius for both the simulation and the experiment. This is due to the appearance of the biaxial stretching state in this region. Hence, it is obvious that the potential failure site in the deep drawing of the part is located in the vicinity of the punch radius where the thinning is a maximum. This phenomenon is also observed by S. Gallée $\mathrm{e}^{12}$ during the deep drawing of stainless-steel sheet.

Although the trend of thickness distribution predicted by the simulation matches with the experiment, more thinning was observed in the simulation $(32 \%)$ than in the experiments $(26 \%)$. The difference in thinning could be attributed to the insufficiency of the tensile test. The flow stress available from the tensile test was limited to small strains at low strain rates. The flow curve of the material was obtained up to the 0.21 plastic strain value in the tensile test. Beyond this value, the hardening curve was extrapolated to high strains using the Ludwick equation. These values were probably overestimated. Thus, more restraining force to draw the material from the flange resulted in a localized thinning of $32 \%$ in the simulation.

\section{CONCLUSIONS}

Finite-element simulations and deep-drawing experiments of the AISI 304 stainless-steel sheet were carried out. The conclusions can be summarized as follow:

- Different constitutive equations were evaluated to represent the plastic behavior of the AISI 304 stainless steel sheet. The Ludwick equation was the best fit to the experimental data for this steel.

- Good agreement was obtained between the experimental and finite-element results. Maximum thinning was observed at the punch radius in both the simula- tion and experiment. This is because of the appearance of the biaxial stretch state at the punch radius.

- Predicted thinning values were larger than the experimental data at the punch radius. More thinning observed in the simulation could be due to the extrapolation of the flow stress to higher strains in the software and overestimated.

\section{Acknowledgements}

The authors would like to thank Mr. Kani Yilmaz for his help with the experimental set-up.

\section{REFERENCES}

${ }^{1}$ A. G. Mamalis, D. E. Manolakos, A. K. Baldoukas, Simulation of sheet metal forming using explicit finite element techniques: effect of material and forming characteristics, Journal of Materials Processing Technology, 72 (1997), 110-116, doi:10.1016/S0924-0136(97) 00137-4

${ }^{2}$ L. F. Menezes, C. Teodosiu, Three-dimensional numerical simulation of the deep-drawing process using solid finite elements, Journal of Materials Processing Technology, 97 (2000), 100-106, doi:10.1016/ S0924-0136(99)00345-3

${ }^{3}$ E. Bayraktar, S. Altintas, Square cup deep drawing and 2D-draw bending analysis of Hadfield steel, Journal of Materials Processing Technology, 60 (1996), 183-190, doi:10.1016/0924-0136(96) 02326-6

${ }^{4}$ Y. Marumo, H. Saiki, Evaluation of the forming limit of aluminum square cups, Journal of Materials Processing Technology, 80-81 (1998), 427-432, doi:10.1016/S0924-0136(98)00196-4

${ }^{5}$ Y. Harada, M. Ueyama, Formability of Pure Titanium Sheet in Square Cup Deep Drawing, Procedia Engineering, 81 (2014), 881-886, doi:10.1016/j.proeng.2014.10.092

${ }^{6}$ L. M. A. Hezam, M. A. Hassan, I. M. Hassab-Allah, M. G. El-Sebaie, Development of a new process for producing deep square cups through conical dies, International Journal of Machine Tools \& Manufacture, 49 (2009), 773-780, doi:10.1016/j.ijmachtools.2009. 04.001 


\section{B. SENER, H. KURTARAN: MODELING THE DEEP DRAWING OF AN AISI 304 STAINLESS-STEEL}

${ }^{7}$ M. Gavas, M. Izciler, Design and application of blank holder system with spiral spring in deep drawing of square cups, Journal of Materials Processing Technology, 171 (2006), 274-282, doi:10.1016/j.jmatprotec.2005.06.082

${ }^{8}$ M. A. Hassan, K. I. E. Ahmed, N. A. Takakura, A developed process for deep drawing of metal foil square cups, Journal of Materials Processing Technology, 212 (2012), 295-307, doi:10.1016/ j.jmatprotec.2011.09.015

${ }^{9}$ L. P. Lei, S. M. Hwang, B. S. Kang, Finite element analysis and design in stainless steel sheet forming and its experimental comparison, Journal of Materials Processing Technology, 110 (2001), 70-77, doi:10.1016/S0924-0136(00)00735-4

${ }^{10} \mathrm{~J}$. H. Lee, B. S. Chun, Investigation on the variation of deep drawability of STS304 using FEM simulations, Journal of Materials Processing Technology, 159 (2005), 389-396, doi:10.1016/ j.jmatprotec.2004.05.029
${ }^{11}$ F. K. Chen, S. Y. Lin, A formability index for the deep drawing of stainless steel rectangular cups, International Journal of Advanced Manufacturing Technology, 34 (2007), 878-888, doi:10.1007/ s00170-006-0659-3

${ }^{12} \mathrm{~S}$. Gallée, P. Pilvin, Deep drawing simulation of a metastable austenitic stainless steel using a two-phase model, Journal of Materials Processing Technology, (2010), 835-843, doi:10.1016/ j.jmatprotec.2010.01.008

${ }^{13}$ F. Ayari, E. Bayraktar, Journal of Achievements in Materials and Manufacturing Engineering, 48 (2011) 1, 64-86

${ }^{14}$ N. C. Da Silva, S. A. G. De Oliveria, E. H. Guimaraes, A Comparative Study of the Constitutive Equations to Predict Work Hardening Characteristics of Stainless Steels 304 and ACE P439A, 20th International Congress of Mechanical Engineering, Brazil, 2009, 1-7 